\title{
TRADUÇÃO COMENTADA DO CONTO “O CÔNEGO OU METAFÍSICA DO ESTILO”, DE MACHADO DE ASSIS
}

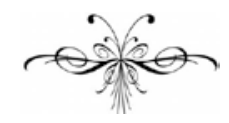

MACHADO DE ASSIS

\author{
ELEONORA FRENKEL BARRETO
}

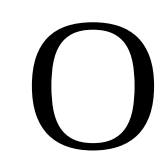

convite $^{1}$ a traduzir e comentar a tradução de um conto de Machado de Assis ao espanhol e integrar um instigante projeto onde os diálogos propostos se ampliam do texto de partida para uma multiplicidade de textos de chegada, em cinco línguas diversas, intermediados por tradutores, leitores e críticos, com suas variadas vozes, provoca ao menos dois grandes desafios: apresentar um texto que possa trazer algum elemento diferencial em relação à outra tradução para o espanhol que faz parte do projeto, além de se mostrar tão qualificada quanto aquelas já publicadas anteriormente e que atestam grande cuidado dos tradutores; e, dificuldade adicional, dialogar, por ora às cegas, com os outros comentários que se farão das respectivas traduções. Que aspectos de análise do conto e que abordagens teórico-conceituais serão priorizadas pelos demais tradutores? Que problemas estarão colocados para reflexões e desdobramentos posteriores? Vejome num jogo de múltiplas vozes que até então conversam silenciosas e ocultas, e que, ao se fazerem ouvir, ressoarão diversas e surpreendentes.

Meu percurso se abre na intersecção entre o exercício da tradução e questões de teoria literária que dinamizam a leitura do texto a ser traduzido. O ponto de partida é a profícua hipótese lançada por Pablo Rocca no prólogo ao volume de Diez historias cortas de Machado de Assis, selecionadas e traduzidas por ele e publicadas por Ediciones de la Banda Oriental, em 2006. A análise de Rocca situa a escrita dos contos de Machado em seu contexto literário, no qual identifica tanto aspectos relativos à sua produção quanto à sua recepção, e aponta um problema quanto à própria configuração desse gênero narrativo no Brasil. Seu argumento é que, em um contexto marcado por uma produção ainda inicial de contos, em que estes não teriam adquirido uma forma que se pudesse dizer característica, e em um espaço de publicações periódicas que imporia alguma dificuldade para a criação artística, Machado consegue subverter tais limitações em potencialidades, fazendo do gênero e

\footnotetext{
${ }^{1}$ Agradeço a Gustavo Althoff e Pablo Cardellino pelo convite e especialmente ao primeiro pelas conversas, considerações e sugestões valiosas durante a realização da tradução e seu comentário.
} 
das revistas onde publica um "campo de provas ou de experimentação técnica que lhe permitiu alcançar resultados inovadores” (Rocca, 2006, p. 10).

A questão que segue é pensar o que daria esse caráter experimental aos contos de Machado e, em particular, ao “Cônego ou Metafísica do Estilo”, bem como que dificuldades específicas isso colocaria ao exercício de sua tradução. Rocca aponta um caminho, ao dizer que uma das experimentações foi "el aprovechamiento de lo circunstancial, introduciendo en el curso de la narración una multiplicidad de voces $y$, por lo tanto, de versiones sobre la anécdota aparentemente simple que se está refiriendo, alterando con sutileza la omnisciencia, refutando la posibilidad de concebir el relato como acto totalizador" (Rocca, 2006. p. 11). Assim como este projeto de traduções e comentários, poder-se-ia dizer que o conto em questão é polifônico e dialógico, ou, que integra uma multiplicidade de vozes cujas diferenças se deixam latentes e com as quais se desunifica a língua, seja explicitando sua estratificação como fenômeno social, seja introduzindo elementos estranhos e inovadores à língua literária. Dito isso, evidencia-se, por um lado, que as considerações de Mikhail Bakhtin sobre o caráter polifônico da prosa literária ${ }^{2}$ se fazem presentes nesta análise e, por outro lado, que a tradução esteve atenta a essa variação de vozes que compõem o conto, e à relevância de sua recriação no texto de chegada.

Dando continuidade, penso a ironia e o "engano"3 como recursos amplamente explorados pelo escritor Machado de Assis, e que intensificam outro aspecto da descentralização e da diversificação da língua, qual seja: a polivalência das palavras, o descolamento do sentido único e a ampliação das significações possíveis. Isso coloca, por sua vez, outra questão para a tradução do conto: diante de ambivalências e "incongruências" observadas no texto, como fazer escolhas que não unifiquem e recentralizem a língua, correndo o risco de promover um achatamento das diversas dimensões da palavra e de atribuir um sentido explicativo que empobreceria o literário no texto.

O que ressoa no parágrafo anterior é o conceito de significação. A partir de uma releitura do signo linguístico definido por Ferdinand de Sausurre, onde se distinguem significante e significado, som e sentido, fala e grafia, Roland Barthes irá pensar a noção de significância: uma "significação circulante", que "não tem nem ponto de partida nem ponto de chegada: ela circula, disseminando sentidos". 5 Essa noção dilui a dicotomia anterior e aponta para uma filosofia da linguagem em que o signo deixa de se entender como oposição entre forma aparente e conteúdo transcendente, e onde o sentido que se pode atribuir a ele se vê ampliado e

\footnotetext{
${ }^{2}$ Em suas reflexões sobre o discurso no romance, Bakhtin destaca o gênero literário como um “fenômeno pluriestilístico, plurilíngue e plurivocal”, diz que "o romance é uma diversidade social de linguagens, organizadas artisticamente, às vezes de línguas e de vozes individuais” e, ainda, que "toda estratificação interna de cada língua em cada momento dado de sua existência histórica constitui premissa indispensável do gênero romanesco”. Embora o objeto da tradução que aqui se comenta não seja um romance, acredito que é possível pensar o conto como gênero que se inscreve dentro daquilo que o mesmo Bakhtin define como "prosa literária” (Ver: Bakhtin, 2010, pp. 73-75).

${ }^{3}$ Entendido como apathe, termo grego que designa a capacidade de engano da palavra, ou seja, que manifesta que esta (o lógos) se constitui de dois patamares: o que manifesta e o que guarda, esconde ou escamoteia (Cf. Lima, 2003, pp. 34-36).

${ }^{4}$ Entendidas como associações de palavras aparentemente incongruentes ou desprovidas de lógica, mas que resultam em composições estilísticas singulares e amplamente significantes.

${ }^{5}$ Conforme a explicação de Leyla Perrone-Moisés (1978, p. 44).
} 
disseminado de acordo com as relações diferencias nas quais se inscreve; ou seja, conforme o modo de composição ou combinação dos signos, eles adquirem significações múltiplas e potencialmente infinitas. ${ }^{6}$ Com base nisso, Barthes irá arriscar uma resposta hipotética para a recorrente pergunta sobre o que é literatura: uma "técnica decepcionante do sentido", que quer dizer que "o escritor se aplica em multiplicar as significações sem as preencher nem fechar, e que utiliza a linguagem para constituir um mundo enfaticamente significante, mas finalmente jamais significado" (2003, p. 173). O texto literário se apresenta, então, como aquele que amplia os sentidos possíveis, que deixa em aberto as perguntas que lança, que se faz refratário à interpretação unívoca e ao fechamento do sentido.

Com isso, o que temos para a tradução literária é o desafio de, tanto quanto possível, não abafar as ressonâncias de sentidos suscitadas pelo texto. Assim como a crítica literária não teria a tarefa de nomear o sentido do texto, ${ }^{7}$ a tradução promoveria seu empobrecimento se o tornasse claro e explicativo ao desfazer dúvidas, ambivalências e "incongruências" colocadas pelo modo de combinação das palavras elaborado pelo escritor.

Da perspectiva de uma teoria da tradução, Antoine Berman elenca uma série de "tendências deformadoras" nas quais provavelmente todo texto traduzido incorre de uma forma ou de outra. Uma delas, a homogeneização, é apontada por ele como aquela que resulta de uma série de outras tendências, a saber: a racionalização, a clarificação, o alongamento, o enobrecimento, o empobrecimento qualitativo e quantitativo. Todas essas tendências, (conceitualmente definidas por Berman de maneira específica e precisa) cada uma a sua maneira, resultaria naquela primeira, cujo principal defeito é aplainar a heterogeneidade constitutiva da prosa literária. Berman dirá: "Frente a uma obra heterogênea - e a obra em prosa o é quase sempre o tradutor tem tendência a unificar, a homogeneizar o que é da ordem do diverso, mesmo do disparate” (2007, p. 55).

O que aponto como dificuldade tradutória ao lidar com a polivalência das palavras no conto de Machado de Assis, potencializada por suas expressões irônicas e seus procedimentos narrativos enganosos, se refere à percepção da importância de recriar seja a amplitude de significações do texto, seja sua heterogeneidade constitutiva. Proponho retomar com um pouco mais de detalhamento as questões escolhidas para o comentário da tradução (a polifonia e a polivalência constitutivas do texto) e exemplificá-las com fragmentos do conto e comparações entre as soluções oferecidas por mim e em duas outras traduções, a saber: a de Santiago Kovadloff (Biblioteca Ayacucho, 1978) e a de Pablo Cardellino (Ediciones Cruz del Sur, 2012).

"O cônego ou metafísica do estilo" aparece por primeira vez no jornal Gazeta de Notícias, em 22 de novembro de 1885, e onze anos depois (1896) passa a integrar a coletânea Várias Histórias, que reúne dezesseis contos publicados nesse jornal entre 1884 e 1891. Essa narrativa curta surge, então, após Memórias póstumas de Brás Cubas, de 1881, peça apontada como um “divisor de águas na obra

\footnotetext{
${ }^{6}$ Nesse sentido, Jacques Derrida irá pensar a noção de rastro que torna indiscerníveis o fora e o dentro do signo, que articula a fala e a escritura, e cuja significação só acontece no contato rastro a rastro (Ver: Gramatologia, 2011).

${ }^{7}$ Faço esta observação com base na reflexão de Roland Barthes que diz que assim como o artista, “o analista refaz o caminho do sentido, ele não tem que designá-lo”, “ele diz o lugar do sentido mas não o nomeia”(2003, p. 55).
} 
machadiana”. No Prólogo à edição de Cuentos (Biblioteca Ayacucho, 1978), Alfredo Bosi diz, em tradução ao espanhol:

Quien recorre los cuentos y, paralelamente, las novelas de la década del 70, está preparado para encontrar la resolución de un desequilibrio. El vino nuevo rompe los odres viejos. A medida que en el escritor crecía la sospecha de que el engaño es necesidad, de que la apariencia funciona universalmente como esencia, tanto de la vida pública como de la intimidad del alma, su narrativa es llevada a asumir una perspectiva más general y, al mismo tiempo, más problemática, más amante de los contrastes. Interiormente se rompe el punto de vista todavía oscilante de los primeros cuentos. (Bosi, 1978, p. xiv)

Bosi nos apresenta a ideia de que cresce nas narrativas de Machado de Assis a suspeita de que "o engano é necessidade” e de que elas são levadas a assumir uma perspectiva mais geral, mais problemática e mais amante dos contrastes. A análise de Nádia Gotlib, por sua vez, diz que o escritor amplia em seus textos as ambiguidades e incertezas:

O modo pelo qual o contista Machado representa a realidade traz consigo a sutileza em relação ao não-dito, que abre para as ambiguidades, em que vários sentidos dialogam entre si. Portanto, nos seus contos, paralelamente ao que acontece, há sempre o que parece estar acontecendo. E disto nunca chegamos a ter certeza. Afinal, o que acontece mesmo? Qual é a estória? E como acontece? Ou qual é o enredo? Isto tudo é montado a partir dos gestos, olhares, cochichos e entrelinhas. (Gotlib, 1985, p. 78)

Sabemos, portanto, que ao lermos os contos de Machado de Assis nos deparamos com narradores traiçoeiros e narrativas elípticas, ambíguas, incertas e duvidosas, que fisgam o leitor pelas questões não resolvidas e pelos sentidos não expressos, sugeridos. Como podemos observar essas características no conto a ser traduzido e em que momentos em particular elas intensificam a necessidade de reflexão para tomar as decisões tradutórias?

A narrativa se inicia em discurso direto, num diálogo entre personagens não apresentados e que, em suas falas, promovem inversões sintáticas estranhas, cortes abruptos que não terminam de preencher um sentido, elipses e pontos suspensivos que deixam em aberto as possibilidades de interpretação semântica. O diálogo, além disso, não parece estabelecer uma relação sequencial ou causal de pergunta e resposta; mais parecem duas falas estrangeiras que se enfrentam sem se ouvir. Em seguida, vem o narrador com seu discurso indireto, referindo-se às personagens que conversam no instante anterior; mas, a continuidade da narração se interrompe para uma mudança de perspectiva: seu discurso passa de $3^{\mathrm{a}}$ a $2^{\mathrm{a}}$ pessoa e ele desloca sua voz para o leitor, justificando-se como texto e desafiando o leitor a enfrentar incrédulo o que lerá. Temos, então, um procedimento narrativo que nos primeiros parágrafos confunde o leitor, lançando-o a um tempo e espaço indefinidos e ao conhecimento de dois personagens inusuais: um substantivo e um adjetivo que conversam em linguagem estranha. E quando a narrativa parece que vai se iniciar, explicando-se, ocorre um abrupto corte que desloca a fala para o leitor, assumindo um registro informal e um tom irônico de enfrentamento.

O deslocamento da narrativa, que se volta para o leitor e abandona o relato das personagens, corta qualquer pretensão de efeito de realidade. Em vez de fazer uso exclusivamente de um narrador "neutro" em terceira pessoa, que contaria a sucessão 
de ações do conto como se esses se desenrolassem sem sua intervenção, o narrador interveniente de Machado explicita desde um primeiro momento que o espaço da narrativa se cria como composição discursiva e como manipulação da linguagem. Com isso, pode-se destacar um problema lançado sobre o conceito de mímesis como imitação ou representação da realidade, mediante uma linguagem que se oferece transparente e mediadora. O "Cônego ou Metafísica do Estilo" expõe a prosa literária como um artifício de linguagem e aponta para a questão da mímesis como um problema, na medida em que explora a capacidade de persuasão e de engano da palavra. ${ }^{8}$

O diálogo entre narrador e leitor que se interpola no relato dos eventos provoca uma sobreposição dos tempos da narrativa e da leitura, ou seja, o tempo do conto não se situa nele mesmo, mas se atualiza no momento em que este é enfrentado pelo leitor. Esse procedimento opera também de modo a desfazer o efeito de realidade do conto, que, deixando de se situar num tempo específico e nomeado, assume nova temporalidade a cada leitura e se refaz nela. Um exemplo disso é a passagem em que o cônego lê o jornal e o faz "agora de manhã"; esse "agora" atualiza o tempo do conto na leitura. A tradução de Kovadloff, entretanto, opta por situar o tempo do conto nele mesmo, retirando o "agora” e substituindo-o pela manhã seguinte:

\begin{tabular}{|c|c|c|c|}
\hline Machado de Assis & $\begin{array}{l}\text { Santiago } \\
\text { Kovadloff }\end{array}$ & Pablo Cardellino & $\begin{array}{c}\text { Eleonora Frenkel } \\
\text { Barreto }\end{array}$ \\
\hline $\begin{array}{l}\text { "Este 'ornamento } \\
\text { do clero' tirou ao } \\
\text { cônego a vontade } \\
\text { de almoçar, quando } \\
\text { ele o leu agora de } \\
\text { manhã”. }\end{array}$ & $\begin{array}{l}\text { “Este ‘oropel del } \\
\text { clero’ le quitó al } \\
\text { canónigo las ganas } \\
\text { de almorzar, } \\
\text { cuándo él lo leyó a } \\
\text { la mañana } \\
\text { siguiente”. }\end{array}$ & $\begin{array}{l}\text { “Este 'ornamento } \\
\text { del clero' le sacó al } \\
\text { canónigo las ganas } \\
\text { de almorzar, } \\
\text { cuando lo leyó } \\
\text { ahora de mañana”. }\end{array}$ & $\begin{array}{lrr}\text { “Eso } & \text { de } \\
\text { ‘ornamento } & \text { del } \\
\text { clero’ le sacó al } \\
\text { canónigo las ganas } \\
\text { de } & \text { almorzar, } \\
\text { cuando lo leyó } \\
\text { ahora por } & \text { la } \\
\text { mañana”. } & & \\
\end{array}$ \\
\hline
\end{tabular}

As dúvidas e incertezas que compõem o conto e que ampliam suas significações se manifestam em composições estilísticas inovadoras, algumas com ocorrência específica em Machado de Assis, de modo que o desafio da tradução é manter essas expressões com toda sua latência de sentidos. No contexto do new

\footnotetext{
${ }^{8}$ Como explica Luiz Costa Lima, é quando a palavra (lógos) passa a ser vista “como uma entidade capaz de manipulação da peithó (persuasão) e formada por dois patamares: o que manifesta e o que guarda, a apate (engano)", que passa a haver condições para que a mímesis se constitua como problema (2003, p. 36). Até fins do séc. VI, segundo Costa Lima, palavra, memória e verdade (alétheia) se associavam de modo inequívoco; o poeta era aquele capaz de fixar a palavra pela memória, o que lhe concedia grande importância: “Mnemosyne é a viga-mestra da indagação da verdade. Daí a importância que assumia o poeta [...]. Através do louvor do poeta, organiza-se o campo da alétheia: ela é palavra, é luz e memória, a que se opõe o campo do esquecimento, de Léthe” (2003, p. 32). O lugar de onde era falada conferia à palavra o caráter de verdade e realidade. É a tragédia que passa a tematizar o engano. Costa Lima diz que: "Desde que a palavra encontrou uma situação social em que pôde desenvolver a ambiguidade sob a forma de atualização do contraditório, deixou de aparecer como palavra una e se mostrou biface, palavra em dobra. A dobra da palavra significa sua força de engano, sua capacidade de conduzir para este ou para aquele rumo” (2003, p. 43).
} 
criticism anglo-saxão e das proposições da leitura microscópica do texto literário (close reading), Cleanth Brooks faz algumas considerações sobre o que chama de "efeito dramático". Segundo ele, a "significação de um poema reside nos complexos pontos de vista", de modo que a análise desse poema implicaria "descobrir as tonalidades particulares que definem esses pontos de vista”. E a tonalidade, por sua vez, seria derivada da "exploração, por parte do poeta, da polivalência das palavras e das associações às quais se prestam, bem como da posição do locutor em relação a cada um dos diferentes níveis de significação". Finalmente, o "efeito dramático" seria proveniente "da confusão, da não-congruência ou da interpenetração de dois ou vários níveis de significação" (Brooks apud Cohen, 1983, pp. 17-18). E essa nãocongruência seria percebida de modo mais explícito na ironia, e seria reforçada pelo paradoxo e pela ambiguidade. Embora Brooks se refira aqui ao gênero poético e ainda que não nos situemos no campo analítico do new criticism, trago à tona essa reflexão para abordar algumas passagens do conto de Machado em que a mencionada variação de perspectiva do narrador se combina com associações singulares de palavras que complicam a atribuição de sentido unívoco e, com isso, impõem dificuldades para a tradução. Além disso, a ironia machadiana vem a ampliar certa confusão para identificar e fixar um sentido ao texto, o que, por sua vez, também implica problemas específicos para a tradução.

Vejamos algumas passagens em que se concentram esses "nódulos de incerteza"9 ou essas zonas inquietantes em que o texto se abre para a multiplicidade de significações, e em que o tradutor corre o risco de lhe encerrar um sentido. No primeiro exemplo, um corte de cabelo definido de modo tão singular deixa no ar uma indefinição; afinal, ao se dizer "cabelos cortados à cabeça do Sol ou da Noite”, de que tipo de corte se estaria falando? Qualquer hipótese de interpretação e de tradução nela baseada apresentaria tantas possibilidades de equívoco quanto de acerto. A tradução literal, neste caso, creio, opera, nas três traduções, de modo a manter a indecisão no texto de chegada:

1.

\begin{tabular}{|c|c|c|c|}
\hline Machado de Assis & $\begin{array}{l}\text { Santiago } \\
\text { Kovadloff }\end{array}$ & Pablo Cardellino & $\begin{array}{c}\text { Eleonora Frenkel } \\
\text { Barreto }\end{array}$ \\
\hline $\begin{array}{l}\text { "Passai, olhos de } \\
\text { toda cor, forma de } \\
\text { toda casta, cabelos } \\
\text { cortados à cabeça } \\
\text { do Sol ou da } \\
\text { Noite". }\end{array}$ & $\begin{array}{l}\text { "Pasad, ojos de } \\
\text { todo color, formas } \\
\text { de todo tipo, } \\
\text { cabellos cortados } \\
\text { de la cabeza del } \\
\text { Sol o de la Noche". }\end{array}$ & $\begin{array}{l}\text { "Pasad, ojos de } \\
\text { todo color, forma } \\
\text { de toda especie, } \\
\text { cabellos cortados a } \\
\text { la cabeza del Sol o } \\
\text { la Noche". }\end{array}$ & $\begin{array}{l}\text { "Pasad, ojos de } \\
\text { todo color, forma } \\
\text { de toda casta, } \\
\text { cabellos cortados a } \\
\text { la cabeza del Sol o } \\
\text { de la Noche". }\end{array}$ \\
\hline
\end{tabular}

\footnotetext{
${ }^{9}$ Expressão que tomo de empréstimo a Gustavo Althoff, baseada na leitura de Anthony Pym, que diz que nunca podemos estar inteiramente certos do sentido daquilo que traduzimos e que devemos, portanto, admitir a incerteza e traduzir com e a despeito dela: "The basic idea here is that we can never be entirely sure of the meanings that we translate. We thus have to admit we are uncertain about what we translate, and yet we must try to translate nevertheless" (Pym, 2010, p. 91).
} 
No segundo fragmento destacado, a expressão "galé do espírito" amplia as possibilidades de significação do excerto em que figura, na medida em que galé (como substantivo feminino) tem como acepção primeira uma embarcação. Kovadloff e Cardellino optaram por esse sentido do termo, que suspende muito mais a significação ao ser atribuído ao espírito. A expressão, no contexto, e em última instância, suspende o sentido. Em minha tradução, por sua vez, tomei como referência o significado atribuído ao termo de galé como substantivo masculino, tal como o teria usado Machado: "Pessoa condenada a cumprir pena de trabalhos forçados, como remador, a bordo das galés”. ${ }^{10}$ A partir dessa interpretação, o termo escolhido para minha tradução foi réprobo: "condenado a las penas eternas" ou pessoa "condenada por su heterodoxia religiosa". ${ }^{11}$ A escolha feita termina por atribuir um sentido preciso à expressão.

2.

\begin{tabular}{|l|l|l|l|}
\hline Machado de Assis & $\begin{array}{c}\text { Santiago } \\
\text { Kovadloff }\end{array}$ & Pablo Cardellino & $\begin{array}{l}\text { Eleonora Frenkel } \\
\text { Barreto }\end{array}$ \\
\hline $\begin{array}{l}\text { "Toda a natureza } \\
\text { parece assim bater } \\
\text { palmas ao regresso } \\
\text { daquele galé do do la naturaleza } \\
\text { espírito". }\end{array}$ & $\begin{array}{l}\text { parece así aplaudir } \\
\text { el regreso de } \\
\text { aquella galera del } \\
\text { espíritu”. }\end{array}$ & $\begin{array}{l}\text { parece así aplaudir } \\
\text { el regreso de } \\
\text { aquella galera del } \\
\text { espíritu”. }\end{array}$ & $\begin{array}{l}\text { "Toda la naturaleza } \\
\text { parece así aplaudir } \\
\text { réprobo regreso de aquél } \\
\text { espíritu”. }\end{array}$ \\
\hline
\end{tabular}

No terceiro fragmento, há algumas locuções propriamente machadianas (destacadas em itálico), das quais não se encontram outras ocorrências noutros textos, de outros autores, o que implica maiores dificuldades e mais diversidade nas escolhas tradutórias - além de ser um parágrafo particularmente rico por apresentar sucessivas locuções que desdobram uma primeira imagem: "Células de ideias novas", criando novas associações e ilustrando-a de modo lúdico, sem chegar a explicá-la. As duas primeiras traduções parecem optar por termos explicativos para a expressão "rugas extintas", atribuindo-lhe um sentido que a aproxima do campo semântico de "rusga", desavença ou desentendimento. A tradução literal, nesse caso, contribui para manter em aberto o sentido dessas "dobras" que se escondem na cabeça do cônego e que se mesclam a outros resquícios de ideias e sensações. Por outro lado, a tradução literal para "regas de voltarete" foi unânime e permitiu conservar a imagem criada no texto de partida.

3.

\footnotetext{
${ }^{10}$ Cf. Aulete, Dicionário Digital.

${ }^{11}$ Cf. Dicionário da Real Academia Espanhola.
} 


\begin{tabular}{|c|c|c|c|}
\hline Machado de Assis & $\begin{array}{l}\text { Santiago } \\
\text { Kovadloff }\end{array}$ & Pablo Cardellino & $\begin{array}{c}\text { Eleonora Frenkel } \\
\text { Barreto }\end{array}$ \\
\hline 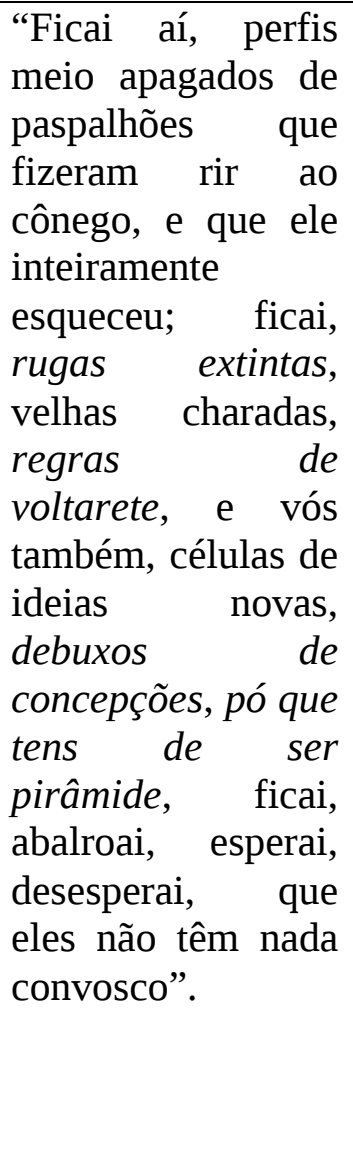 & $\begin{array}{l}\text { “Quedaos ahí, } \\
\text { perfiles } \\
\text { semiborrados de } \\
\text { necios que hicieron } \\
\text { reír al canónigo, y } \\
\text { que él enteramente } \\
\text { olvidó; no os } \\
\text { mováis, riñas } \\
\text { extintas, viejos } \\
\text { acertijos, reglas de } \\
\text { tresillo, y vosotras } \\
\text { también, células de } \\
\text { ideas nuevas, } \\
\text { bosquejos } \\
\text { concepciones, } \\
\text { polvo que tenéis } \\
\text { que llegar a ser } \\
\text { pirámide, } \\
\text { aguardad, } \\
\text { sofrenaos, esperad, } \\
\text { desesperad, que } \\
\text { ellos nada tiene } \\
\text { con vosotros”. }\end{array}$ & $\begin{array}{l}\text { "Quedaos ahí, } \\
\text { perfiles } \\
\text { desdibujados de } \\
\text { mamarrachos que } \\
\text { hicieron reír al } \\
\text { canónigo, y que él } \\
\text { olvidó } \\
\text { completamente; } \\
\text { quedaos, } \\
\text { desaciertos } \\
\text { extinguidos, viejas } \\
\text { charadas, reglas de } \\
\text { tresillo, y vosotros } \\
\text { también, células de } \\
\text { ideas nuevas, } \\
\text { bocetos de } \\
\text { concepciones, } \\
\text { polvo que has de } \\
\text { ser pirámide, } \\
\text { quedaos, atracad, } \\
\text { desesperad, que } \\
\text { ellos no quieren } \\
\text { nada con } \\
\text { vosotros". }\end{array}$ & $\begin{array}{l}\text { "Quedaos ahí, } \\
\text { perfiles } \\
\text { semiborrados de } \\
\text { abombados que } \\
\text { han hecho reír al } \\
\text { canónigo, y que él } \\
\text { ha olvidado } \\
\text { completamente; } \\
\text { quedaos, arrugas } \\
\text { extinguidas, viejos } \\
\text { hacertijos, reglas } \\
\text { de tresillo, y } \\
\text { vosotros también, } \\
\text { células de ideas } \\
\text { nuevas, bocetos de } \\
\text { concepciones, } \\
\text { polvo que tenéis } \\
\text { que ser pirámide, } \\
\text { quedaos, aportad, } \\
\text { esperad, } \\
\text { desesperad, que } \\
\text { ellos no tienen } \\
\text { nada con } \\
\text { vosotros". }\end{array}$ \\
\hline
\end{tabular}

No conto, define-se o estilo como o casamento entre as palavras. Para Bakhtin, ao pensar a prosa literária e, em particular o romance, o estilo não seria uma individuação da língua geral (como o seria para Sausurre), mas sim um modo de composição criado a partir da pluralidade da língua, fazendo do espaço textual um "microcosmo do plurilinguismo": "o romance é uma diversidade social de linguagens organizadas artisticamente, às vezes de línguas e de vozes individuais” (Bakhtin, 2010, p. 74). Ao entender o conto como uma das formas da prosa literária, podemos pensar que seu espaço também se faça propício para uma orquestração de diversas vozes, manifestações da estratificação da língua. A questão que Bakhtin coloca e que se estende aqui é como aparece essa amálgama de discursos na prosa literária e, no caso em exame, no conto de Machado. Segundo o teórico, o plurilinguismo no romance se organiza como "um jogo humorístico com as linguagens, uma narração ‘que não parte do autor' (do narrador, do suposto autor, do personagem)” (Bakhtin, 2010, pp. 126-127).

Machado de Assis, por sua vez, mestre em criar ficções de si mesmo como autor, através de seus narradores que se constituem como autores supostos, ${ }^{12}$ artífice em articular vozes e discursos, em passar de uma pessoa à outra e de uma perspectiva

\footnotetext{
${ }^{12}$ Sobre a ficção de autor e a figura do autor suposto na narrativa de Machado de Assis, ver: Abel B. Baptista, A formação do nome, 2003.
} 
à outra, procede, em "O cônego e o metafísico", de modo a orquestrar ao menos dois grandes estratos da língua: o discurso eclesiástico, parodiado nas vozes do narrador e das personagens; e a fala cotidiana dos leitores de revistas da época, interpelados pelo narrador de modo não apenas informal como intempestivo. As passagens de um a outro se fazem de forma abrupta e surpreendente, sem marcas de distinção, exceto as aspas e o discurso direto nas falas dos personagens (os leitores, o substantivo e o adjetivo).

O adjetivo e o substantivo, como estão em cabeça de padre, assumem a linguagem das Escrituras; parodiando o "velho drama de Judá" e o Cântico, suas falas estão marcadas pelo tom reverencial da segunda pessoa do plural. O narrador, por sua vez, move-se entre a "neutralidade" da terceira pessoa que conta os eventos, a provocação do discurso em segunda pessoa do singular que interpela o leitor e uma voz que se mescla à do cérebro eclesiástico, com a formalidade da segunda pessoa do plural. A linguagem arcaizada se amalgama à língua cotidiana do leitor, promovendo esse aspecto tão característico da narrativa de Machado: a capacidade de se escrever considerando o espaço de sua publicação e seu público receptor. Como destaca Pablo Rocca em sua análise: "Machado pensaba sus historias dentro y no fuera de la existencia material del acto de la lectura y de su entorno" (Rocca, 2006, p. 8). Vejamos como ficam algumas dessas passagens nas traduções:

1.

\begin{tabular}{|c|c|c|c|}
\hline Machado de Assis & $\begin{array}{l}\text { Santiago } \\
\text { Kovadloff }\end{array}$ & Pablo Cardellino & $\begin{array}{c}\text { Eleonora Frenkel } \\
\text { Barreto }\end{array}$ \\
\hline $\begin{array}{l}\text { “- ‘Eu vos conjuro, } \\
\text { filhas de } \\
\text { Jerusalém, que se } \\
\text { encontrardes o meu } \\
\text { amado, lhe façais } \\
\text { saber que estou } \\
\text { enferma de amor...' } \\
\text { Era assim, com } \\
\text { essa melodia do } \\
\text { velho drama de } \\
\text { Judá, que } \\
\text { procuravam um ao } \\
\text { outro na cabeça do } \\
\text { Cônego Matias um } \\
\text { substantivo e um } \\
\text { adjetivo... Não me } \\
\text { interrompas, leitor } \\
\text { precipitado; sei que } \\
\text { não acreditas em } \\
\text { nada do que vou } \\
\text { dizer”. }\end{array}$ & 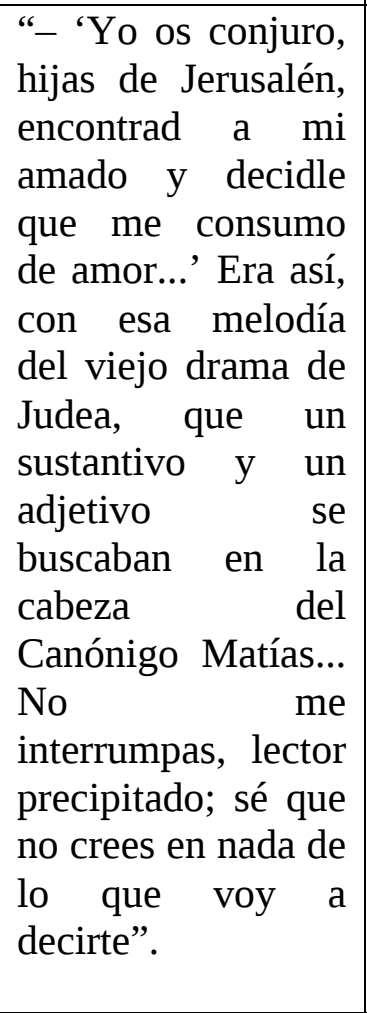 & $\begin{array}{l}\text { “- 'Yo os conjuro, } \\
\text { hijas de Jerusalén, } \\
\text { si encontrareis a mi } \\
\text { amado, hacedle } \\
\text { saber que estoy } \\
\text { enferma de amor...' } \\
\text { Era así, con esa } \\
\text { melodía del viejo } \\
\text { drama de Judea, } \\
\text { que se buscaban } \\
\text { mutuamente en la } \\
\text { cabeza del } \\
\text { canónigo Matías un } \\
\text { sustantivo y un } \\
\text { adjetivo... No me } \\
\text { interrumpas, lector } \\
\text { precipitado; sé que } \\
\text { no crees en nada de } \\
\text { lo que voy a decir”. }\end{array}$ & $\begin{array}{l}\text { “- 'Yo os conjuro, } \\
\text { hijas de Jerusalén, } \\
\text { que si encontráis a } \\
\text { mi amado, le } \\
\text { hagáis saber que } \\
\text { estoy enferma de } \\
\text { amor...' Era así, } \\
\text { con esa melodía } \\
\text { del viejo drama de } \\
\text { Judea, que se } \\
\text { buscaban uno al } \\
\text { otro en la cabeza } \\
\text { del canónigo } \\
\text { Matías un } \\
\text { sustantivo y un } \\
\text { adjetivo... No me } \\
\text { interrumpas, lector } \\
\text { precipitado; sé que } \\
\text { no crees en nada de } \\
\text { lo que voy a } \\
\text { decir.”. }\end{array}$ \\
\hline
\end{tabular}


2.

\begin{tabular}{|c|c|c|c|}
\hline Ido de Assis & $\begin{array}{l}\text { Santiago } \\
\text { Kovadloff }\end{array}$ & Pablo Cardellino & $\begin{array}{c}\text { Eleonora Frenkel } \\
\text { Barreto }\end{array}$ \\
\hline 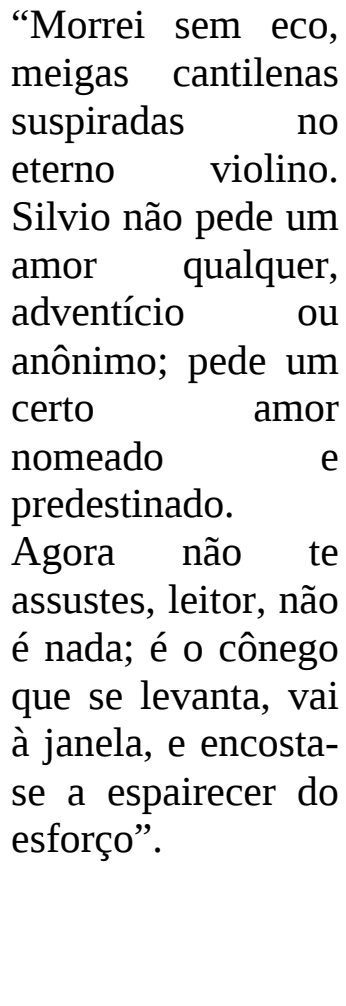 & 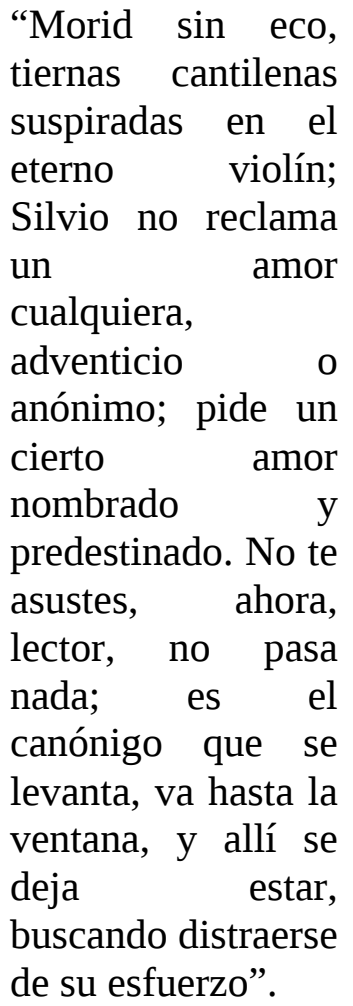 & 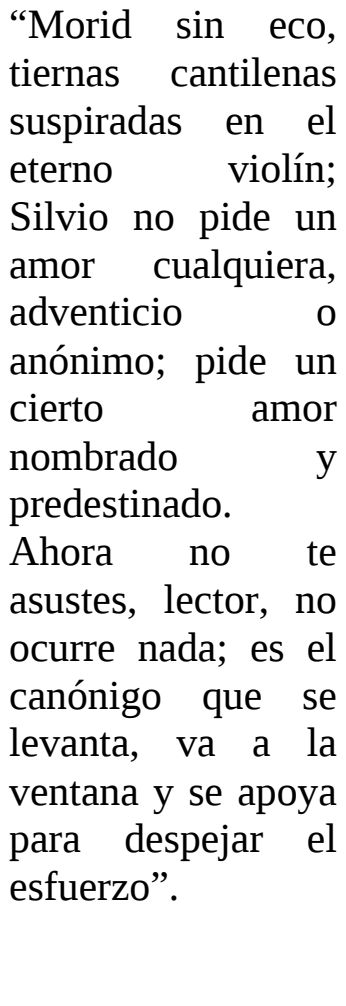 & $\begin{array}{lr}\text { “Morid sin eco, } \\
\text { tiernas cantilenas } \\
\text { suspiradas en el } \\
\text { eterno } & \text { violín; } \\
\text { Silvio no pide un } \\
\text { amor cualquiera, } \\
\text { adventicio } \\
\text { anónimo; pide un } \\
\text { cierto amor } \\
\text { nombrado } \\
\text { predestinado. } \\
\text { Ahora no te } \\
\text { asustes, lector, no } \\
\text { pasa nada; es el } \\
\text { canónigo que se } \\
\text { levanta, va hasta la } \\
\text { ventana, y } \\
\text { recuesta } \\
\text { esparcirse } \\
\text { esfuerzo". }\end{array}$ \\
\hline
\end{tabular}

A comparação das traduções indica poucas variações entre elas e todas resultam, com suas pequenas singularidades, em boas soluções para dar conta da composição de vozes que se apresenta no texto de partida. Dito isso, e fundamentada a análise do conto e o comentário da tradução que inclui a apreciação de algumas já realizadas, percebo que pouco pude contribuir com a ideia inicial de apresentar algum traço diferencial na tradução ao espanhol, ainda que possa ter oferecido, num ou noutro caso, pequenas correções alinhadas com o material original. Considerando a quantidade e a qualidade das traduções desse conto já realizadas, quiçá somente um projeto mais ousado e arriscado pudesse oferecer alguma ruptura no horizonte de expectativas. $^{13}$

\footnotetext{
${ }^{13}$ Vale lembrar que há ao menos duas traduções de "O cônego ou Metafísica do estilo” às quais não tive acesso, em: Varias historias. Prólogo de Antonio Benítez Rojo (La Habana: Casa de las Américas, 1972) e La iglesia del diablo y otros cuentos. Tradução de Remy Gorga Filho (Libresa: Quito, 2007).
} 


\section{O CÔNEGO OU METAFÍSICA DO ESTILO}

— "Vem do Líbano, esposa minha, vem do Líbano, vem... As mandrágoras deram o seu cheiro. Temos às nossas portas toda a casta de pombos..."

— "Eu vos conjuro, filhas de Jerusalém, que se encontrardes o meu amado, lhe façais saber que estou enferma de amor..."

Era assim, com essa melodia do velho drama de Judá, que procuravam um ao outro na cabeça do Cônego Matias um substantivo e um adjetivo... Não me interrompas, leitor precipitado; sei que não acreditas em nada do que vou dizer. Di-lo-ei, contudo, a despeito da tua pouca fé, porque o dia da conversão pública há de chegar.

Nesse dia, - cuido que por volta de 2222, — o paradoxo despirá as asas para vestir a japona de uma verdade comum. Então esta página merecerá, mais que favor, apoteose. Hão de traduzi-la em todas as línguas. As academias e institutos farão dela um pequeno livro, para uso dos séculos, papel de bronze, cortedourado, letras de opala embutidas, e capa de prata fosca. Os governos decretarão que ela seja ensinada nos ginásios e liceus. As filosofias queimarão todas as doutrinas anteriores, ainda as mais definitivas, e abraçarão esta psicologia nova, única verdadeira, e tudo estará acabado. Até lá passarei por tonto, como se vai ver.

Matias, cônego honorário e pregador efetivo, estava compondo um sermão quando começou o idílio psíquico. Tem quarenta anos de idade, e vive entre livros e livros para os lados da Gamboa. Vieram

\section{EL CANÓNIGO O METAFÍSICA DEL ESTILO}

mía, ven de Líbano, ven...Las mandrágoras, le dieron su aroma. Tenemos frente a nuestras puertas toda casta de palomas.

— "Yo os conjuro, hijas de Jerusalén, que si encontráis a mi amado, le hagáis saber que estoy enferma de amor..."

Era así, con esa melodía del viejo drama de Judea, que se buscaban uno al otro en la cabeza del canónigo Matías un sustantivo y un adjetivo... No me interrumpas, lector precipitado; sé que no crees en nada de lo que voy a decir. He de decírtelo, con todo, en que pese tu poca fe, porque el día de la conversión pública ha de llegar.

Ese día, - cuido que sea allí por 2222, - la paradoja se despojará de sus alas para vestir la chaqueta de una verdad común. Entonces esta página merecerá, más que favor, apoteosis. Han de traducirla a todas las lenguas. Las academias e institutos harán de ella un pequeño libro, para uso de los siglos, papel de bronce, corte-dorado, letras de ópalo embutidas y tapa de plata mate. Los gobiernos decretarán que sea enseñada en los gimnasios y liceos. Las filosofías quemarán doctrinas anteriores, aún las más definitivas, y abrazarán esta nueva psicología, única verdadera, y todo estará acabado.

Hasta entonces pasaré por tonto, como se verá.

Matías, canónigo horario y predicador efectivo, componía un sermón cuando empezó el idilio psíquico. Tiene cuarenta años de edad, y vive entre libros y libros hacia los lados de la Gamboa. Vinieron a 
encomendar-lhe o sermão para certa festa próxima; ele que se regalava então com uma grande obra espiritual, chegada no último paquete, recusou o encargo; mas instaram tanto, que aceitou.

- Vossa Reverendíssima faz isto brincando, disse o principal dos festeiros.

$\begin{array}{cccc}\text { Matias } & \text { sorriu manso e } \\ \text { discreto, como devem sorrir os }\end{array}$ eclesiásticos e os diplomatas. Os festeiros despediram-se com grandes gestos de veneração, e foram anunciar a festa nos jornais, com a declaração de que pregava ao Evangelho o Cônego Matias "um dos ornamentos do clero brasileiro". Este "ornamento do clero" tirou ao cônego a vontade de almoçar, quando ele o leu agora de manhã; e só por estar ajustado, é que se meteu a escrever o sermão.

Começou de má vontade, mas no fim de alguns minutos já trabalhava com amor. A inspiração, com os olhos no céu, e a meditação, com os olhos no chão, ficam a um e outro lado do espaldar da cadeira, dizendo ao ouvido do cônego mil coisas místicas e graves. Matias vai escrevendo, ora devagar, ora depressa. As tiras saem-lhe das mãos, animadas e polidas. Algumas trazem poucas emendas ou nenhumas. De repente, indo escrever um adjetivo, suspende-se; escreve outro e risca-o; mais outro, que não tem melhor fortuna. Aqui é o centro do idílio. Subamos à cabeça do cônego.

Upa! Cá estamos. Custou-te, não, leitor amigo? É para que não acredites nas pessoas que vão ao Corcovado, e dizem que ali a impressão da altura é tal, que o homem fica sendo coisa nenhuma. Opinião pânica e falsa, falsa como Judas e outros diamantes. Não creias tu nisso, encargarle el sermón para una fiesta próxima; él, que gozaba en la ocasión con una gran obra espiritual, llegada en la última embarcación, se negó al encargo; sin embargo, insistieron tanto, que aceptó.

- El reverendísimo señor lo hace jugando, dijo el principal de los verbeneros.

Matías sonrió manso y eclesiásticos y los diplomáticos. Los de la verbena se despidieron con grandes gestos de veneración, y fueron a anunciar la fiesta en los diarios, con la declaración de que predicaba al Evangelio el Canónigo Matías, "uno de los ornamentos del clero brasileño". Eso de "ornamento del clero" le sacó al canónigo las ganas de almorzar, cuando lo leyó ahora por la mañana; y solamente por ya estar acordado, es que se metió a escribir el sermón.

Empezó con mala voluntad, pero al cabo de algunos minutos, ya trabajaba con amor. La inspiración, con los ojos hacia el cielo, y la meditación, con los ojos hacia el piso, se disponen a un lado y al otro del respaldo de la silla, suspirando al oído del canónigo mil cosas místicas y graves. Matías sigue escribiendo, a veces despacio, a veces deprisa. Las tiras se le escapan de las manos, animadas y pulidas. Algunas traen pocas enmiendas 0 ninguna. De repente, al prepararse para escribir un adjetivo, se suspende; escribe otro y lo tacha; otro más, que no tiene mejor suerte. Aquí es el centro del idilio. Subamos a la cabeza del canónigo.

- ¡Upa! Ya estamos. Te costó, ¿no es cierto, lector amigo? Es para que no le creas a las personas que suben al Corcovado y dicen que allí la impresión de la altura es tamaña, que el hombre pasa a ser cosa menor. Opinión pánica y falsa, falsa como Judas y otros diamantes. No creas tú en eso, amado 
leitor amado. Nem Corcovados, nem Himalaias valem muita coisa ao pé da tua cabeça, que os mede. Cá estamos. Olha bem que é a cabeça do cônego. Temos à escolha um ou outro dos hemisférios cerebrais; mas vamos por este, que é onde nascem os substantivos. Os adjetivos nascem no da esquerda. Descoberta minha, que, ainda assim, não é a principal, mas a base dela, como se vai ver. Sim, meu senhor, os adjetivos nascem de um lado, e os substantivos de outro, e toda a sorte de vocábulos está assim dividida por motivo da diferença sexual...

\section{- Sexual?}

Sim, minha senhora, sexual. As palavras têm sexo. Estou acabando a minha grande memória psico-léxicológica, em que exponho e demonstro esta descoberta. Palavra tem sexo. às outras?

- Mas, então, amam-se umas

Amam-se umas às outras. $\mathrm{E}$ casam-se. O casamento delas é o que chamamos estilo. Senhora minha, confesse que não entendeu nada.

— Confesso que não.

Pois entre aqui também na cabeça do cônego. Estão justamente a suspirar deste lado. Sabe quem é que suspira? é o substantivo de há pouco, o tal que o cônego escreveu no papel, quando suspendeu a pena. Chama por certo adjetivo, que lhe não aparece: “Vem do Líbano, vem...” E fala assim, pois está em cabeça de padre; se fosse de qualquer pessoa do século, a linguagem seria a de Romeu: "Julieta é o sol... ergue-te, lindo sol." Mas em cérebro eclesiástico, a linguagem é a das Escrituras. Ao cabo, que importam fórmulas? Namorados de Verona ou de Judá falam todos o mesmo idioma, como acontece com o thaler ou o dólar, o florim ou a libra, que é tudo o mesmo dinheiro. lector. Ni Corcovados, ni Himalayas valen mucha cosa al pie de tu cabeza, que los mide. Acá estamos. Observa bien que es la cabeza del canónigo. Tenemos uno u otro de los hemisferios cerebrales para elegir; pero vamos por este, que es donde nacen los sustantivos. Los adjetivos nacen en el de la izquierda. Una descubierta mía, que aún así no es la principal, sino la base de ella, como se verá. Sí, mi señor, los adjetivos nacen de un lado, y los sustantivos de otro, y toda la suerte de vocablos está de esa manera dividida por motivo de la diferencia sexual...

- ¿Sexual?

Sí, mi señora, sexual, Las palabras tienen sexo. Estoy concluyendo mi gran memoria psicoléxico-lógica, en la que expongo y demuestro esta descubierta. La palabra tiene sexo.

unas a las otras?

- ¿Pero entonces se aman

Se aman unas a las otras. Y se

casan. Su casamiento es lo que llamamos estilo. Señora mía, confiese que no ha entendido nada.

- Confieso que no.

Entonces entre aquí también a la cabeza del canónigo. Están justamente suspirando de este lado. ¿Sabe quien suspira? Es el sustantivo de hace poco, aquel que el canónigo escribió en el papel, cuando suspendió la pluma. Clama por cierto adjetivo, que no le aparece: "Ven de Líbano, ven...” Y habla así, pues está en cabeza de cura; si fuese de cualquier otra persona del siglo, el lenguaje sería el de Romeo: "Julieta es el sol...álzate, lindo sol.” Pero en cerebro eclesiástico, el lenguaje es el de las Escrituras. Al fin, ¿qué importan las fórmulas? Enamorados de Verona o de Judá hablan todos el mismo idioma, como ocurre con el thaler o el dólar, el florín o la libra, que es toda la misma plata. 
Portanto, vamos lá por essas circunvoluções do cérebro eclesiástico, atrás do substantivo que procura 0 adjetivo. Sílvio chama por Sílvia. Escutai; ao longe parece que suspira também alguma pessoa; é Sílvia que chama por Sílvio.

Ouvem-se agora e procuramse. Caminho difícil e intrincado que é este de um cérebro tão cheio de coisas velhas e novas! Há aqui um burburinho de idéias, que mal deixa ouvir os chamados de ambos; não percamos de vista o ardente Sílvio, que lá vai, que desce e sobe, escorrega e salta; aqui, para não cair, agarra-se a umas raízes latinas, ali abordoa-se a um salmo, acolá monta num pentâmetro, e vai sempre andando, levado de uma força íntima, a que não pode resistir.

De quando em quando, aparece-lhe alguma dama — adjetivo também - e oferece-lhe as suas graças antigas ou novas; mas, por Deus, não é a mesma, não é a única, a destinada $a b$ eterno para este consórcio. E Sílvio vai andando, à procura da única. Passai, olhos de toda cor, forma de toda casta, cabelos cortados à cabeça do Sol ou da Noite; morrei sem eco, meigas cantilenas suspiradas no eterno violino; Sílvio não pede um amor qualquer, adventício ou anônimo; pede um certo amor nomeado e predestinado.

Agora não te assustes, leitor, não é nada; é o cônego que se levanta, vai à janela, e encosta-se a espairecer do esforço. Lá olha, lá esquece o sermão e o resto. O papagaio em cima do poleiro, ao pé da janela, repete-lhe as palavras do costume e, no terreiro, o pavão enfuna-se todo ao sol da manhã; o próprio sol, reconhecendo o cônego, manda-lhe um dos seus fiéis raios, a cumprimentá-lo. E o raio vem, e pára diante da janela: "Cônego ilustre, aqui
Por lo tanto, sigamos por las circunvoluciones del cerebro eclesiástico, atrás del sustantivo que busca al adjetivo. Silvio clama por Silvia. Escuchad; a lo lejos parece que suspira también una persona; es Silvia que clama por Silvio.

Se escuchan ahora $y$ se buscan. ¡Qué camino difícil y enredado es el de un cerebro tan lleno de cosas viejas y nuevas! Hay aquí tal murmurio de ideas que casi no se dejan oír los clamores de ambos; no perdamos de vista al ardiente Silvio, que allí sigue, que sube y baja, resbala y salta; aquí, para no caerse, se agarra a unas raíces latinas; allí, se arrima a un salmo; más allá, monta a un pentámetro, y sigue siempre andando, lo conduce una fuerza íntima a la que ya no puede resistir.

De cuando en cuando, se le aparece alguna dama - adjetivo también - y le ofrece sus encantos antiguos o nuevos; pero, por Dios, no es la misma, no es la única, la destinada $a b$ eterno para este consorcio. Y Silvio sigue andando, en búsqueda de la única. Pasad, ojos de todo color, forma de toda casta, cabellos cortados a la cabeza del Sol o de la Noche; morid sin eco, tiernas cantilenas suspiradas en el eterno violín; Silvio no pide un amor cualquiera, adventicio o anónimo; pide un cierto amor nombrado $y$ predestinado.

Ahora no te asustes, lector, no pasa nada; es el canónigo que se levanta, va hasta la ventana, y se recuesta para esparcirse del esfuerzo. Hacia allá mira, hacia allá se olvida el sermón y el resto. El papagayo en su palo, al pie de la ventana, le repite las palabras como de costumbre y, en el terreno, el pavo se explaya al sol de la mañana; el mismo sol, al reconocerlo al canónigo, manda uno de sus fieles rayos a saludarlo. Y el rayo viene, y se 
venho trazer os recados do sol, meu senhor e pai." Toda a natureza parece assim bater palmas ao regresso daquele galé do espírito. Ele próprio alegra-se, entorna os olhos por esse ar puro, deixa-os ir fartarem-se de verdura e fresquidão, ao som de um passarinho e de um piano; depois fala ao papagaio, chama o jardineiro, assoa-se, esfrega as mãos, encosta-se. Não lhe lembra mais nem Sílvio nem Sílvia.

Mas Sílvio e Sílvia é que se lembram de si. Enquanto o cônego cuida em coisas estranhas, eles prosseguem em busca um do outro, sem que ele saiba nem suspeite nada. Agora, porém, o caminho é escuro. Passamos da consciência para a inconsciência, onde se faz a elaboração confusa das idéias, onde as reminiscências dormem ou cochilam. Aqui pulula a vida sem formas, os germens, e os detritos, os rudimentos e os sedimentos; é o desvão imenso do espírito. Aqui caíram eles, à procura um do outro, chamando e suspirando. Dê-me a leitora a mão, agarre-se o leitor a mim, e escorreguemos também.

Vasto mundo incógnito. Sílvio e Sílvia rompem por entre embriões e ruínas. Grupos de idéias, deduzindo-se à maneira de silogismos, perdem-se no tumulto de reminiscências da infância e do seminário. Outras idéias, grávidas de idéias, arrastam-se pesadamente, amparadas por outras idéias virgens. Coisas e homens amalgamam-se; Platão traz os óculos de um escrivão da câmara eclesiástica; mandarins de todas as classes distribuem moedas etruscas e chilenas, livros ingleses e rosas pálidas; tão pálidas, que não parecem as mesmas que a mãe do cônego plantou quando ele era criança. Memórias pias e familiares cruzam-se e confundem-se. Cá estão as vozes detiene frente a la ventana: "Canónigo ilustre, aquí le vengo a traer los mensajes del sol, mi padre y señor." Toda la naturaleza parece así aplaudir al regreso de aquél réprobo del espíritu. Él mismo se alegra, derrama los ojos por ese aire puro, deja que se vayan a hartar de verdura y frescor, al sonido de un pajarito y de un piano; después le habla al papagayo, llama al jardinero, se asuena, refriega las manos, se recuesta. No se acuerda más ni de Silvio ni de Silvia.

Pero Silvio y Silvia sí se recuerdan. Mientras el canónigo se ocupa de cosas raras, ellos prosiguen buscando uno al otro, sin que él sepa o sospeche de nada. Ahora, sin embargo, el camino se hace oscuro. Pasamos de la conciencia a la inconsciencia, en donde se realiza una confusa elaboración de ideas, en donde las reminiscencias dormitan o descansan. Aquí sobresale la vida sin formas, los gérmenes y los detritos, los rudimentos y los sedimentos; es el desván inmenso del espíritu. Aquí cayeron ambos, buscando uno al otro, clamando y suspirando. Deme la lectora la mano, agárrese el lector de mí, y resbalémonos también.

Inmenso mundo incógnito. Silvio y Silvia rompen por entre embriones y ruinas. Grupos de ideas que se deducen a manera de silogismos, que se pierden en el alboroto de reminiscencias de la infancia y del seminario. Otras ideas, preñas de ideas, se arrastran pesadamente, amparadas por otras ideas vírgenes. Cosas y hombres se entremezclan; Platón lleva las gafas de un escribano de la cámara eclesiástica; mandarines de toda clase distribuyen monedas etruscas y chilenas, libros ingleses y rosas pálidas; tan pálidas, que no parecen las mismas que la madre del canónigo plantó cuando era chico. Memorias vanas y familiares se 
remotas da primeira missa; cá estão as cantigas da roça que ele ouvia cantar às pretas, em casa; farrapos de sensações esvaídas, aqui um medo, ali um gosto, acolá um fastio de coisas que vieram cada uma por sua vez, e que ora jazem na grande unidade impalpável e obscura.

minha...

- Vem do Líbano, esposa

- Eu vos conjuro, filhas de Jerusalém...

Ouvem-se cada vez mais perto. Eis aí chegam eles às profundas camadas de teologia, de filosofia, de liturgia, de geografia e de história, lições antigas, noções modernas, tudo à mistura, dogma e sintaxe. Aqui passou a mão panteísta de Spinoza, às escondidas; ali ficou a unhada do Doutor Angélico; mas nada disso é Sílvio nem Sílvia. E eles vão rasgando, levados de uma força íntima, afinidade secreta, através de todos os obstáculos e por cima de todos os abismos. Também os desgostos hão de vir. Pesares sombrios, que não ficaram no coração do cônego, cá estão, à laia de manchas morais, e ao pé deles o reflexo amarelo ou roxo, ou o que quer que seja da dor alheia e universal. Tudo isso vão eles cortando, com a rapidez do amor e do desejo.

Cambaleias, leitor? Não é o mundo que desaba; é o cônego que se sentou agora mesmo. Espaireceu à vontade, tornou à mesa do trabalho, e relê o que escreveu, para continuar; pega da pena, molha-a, desce-a ao papel, a ver que adjetivo há de anexar ao substantivo.

Justamente agora é que os dois cobiçosos estão mais perto um do outro. As vozes crescem, o entusiasmo cresce, todo o Cântico passa pelos lábios deles, tocados de febre. Frases cruzan y se confunden. Acá están las remotas voces de la primera misa; acá están los cantares del campo que oía entonar a las negras, en casa; harapos de sensaciones desvanecidas, un miedo por aquí, un gusto por allí, disgustos dispersos más allá, que vinieron cada uno a su vez, y que ahora reposan en la gran unidad impalpable y obscura.

mía...

- Ven de Líbano, esposa Jerusalén...

- Yo os conjuro, hijas de

Se escuchan cada vez más cerca. Llegan a las profundas capas de teología, de filosofía, de liturgia, de geografía y de historia, lecciones antiguas, nociones modernas, todo se mezcla, dogma y sintaxis. Aquí ha pasado la mano panteísta de Spinoza, a escondidas; allí ha quedado la uñada del Doctor Angélico; pero nada de eso es Silvio ni Silvia. Y ellos van rompiendo, llevados de una fuerza íntima, afinidad secreta, cruzando todos los obstáculo y por sobre todos los abismos. Los disgustos también han de venir. Sombríos pesares, que no han quedado en el corazón del canónigo, acá están, a la manera de manchas morales y, a sus pies, el reflejo amarillo o malva, o cualquier cosa que sea del dolor ajeno y universal. Todo eso van ellos cortando, con la rapidez del amor y del deseo.

¿Tambaleas, lector? No es el mundo que se viene abajo; es el canónigo que se ha sentado ahora mismo. Se ha esparcido a gusto, volvió a la mesa de trabajo, y relee lo que escribió, para continuar; toma la pluma, la moja, baja hacia el papel, a ver qué adjetivo va a adjuntar al sustantivo.

Justamente ahora los dos codiciosos están más cerca uno al otro. Las voces crecen, el entusiasmo crece, todo el Cántico pasa por sus labios, tocados de fiebre. Frases alegres, 
alegres, anedotas de sacristia, caricaturas, facécias, disparates, aspectos estúrdios, nada os retém, menos ainda os faz sorrir. Vão, vão, o espaço estreita-se. Ficai aí, perfis meio apagados de paspalhões que fizeram rir ao cônego, e que ele inteiramente esqueceu; ficai, rugas extintas, velhas charadas, regras de voltarete, e vós também, células de idéias novas, debuxos de concepções, pó que tens de ser pirâmide, ficai, abalroai, esperai, desesperai, que eles não têm nada convosco. Amam-se e procuram-se.

Procuram-se e acham-se. Enfim, Sílvio achou Sílvia. Viram-se, caíram nos braços um do outro, ofegantes de canseira, mas remidos com a paga. Unem-se, entrelaçam os braços, e regressam palpitando da inconsciência para a consciência. "Quem é esta que sobe do deserto, firmada sobre o seu amado?”, pergunta Sílvio, como no Cântico; e ela, com a mesma lábia erudita, responde-lhe que "é o selo do seu coração", e que "o amor é tão valente como a própria morte".

Nisto, o cônego estremece. O rosto ilumina-se-lhe. A pena, cheia de comoção e respeito, completa o substantivo com o adjetivo. Sílvia caminhará agora ao pé de Sílvio, no sermão que o cônego vai pregar um dia destes, e irão juntinhos ao prelo, se ele coligir os seus escritos, o que não se sabe. anécdotas de sacristía, caricaturas, chistes, disparates, aspectos estrafalarios, nada los detiene, menos aún los hace sonreír. Siguen, siguen, el espacio se reduce. Quedaos ahí, perfiles semiborrados de abombados que han hecho reír al canónigo, y que él ha olvidado completamente; quedaos, arrugas extinguidas, viejos acertijos, reglas de tresillo, y vosotros también, células de ideas nuevas, bocetos de concepciones, polvo que tenéis que ser pirámide, quedaos, aportad, esperad, desesperad, que ellos no tienen nada con vosotros. Se aman y se buscan.

Se buscan y se encuentran. En fin, Silvio encontró a Silvia. Se vieron, se entregaron en brazos mutuos, jadeantes de cansancio, pero redimidos con el pago, Se unen, se entrelazan los brazos, y regresan pulsando de la inconsciencia a la consciencia. “¿Quién es esta que sube del desierto, apoyada sobre su amado?”, pregunta Silvio, como en el Cántico; y ella, con la misma labia erudita, le contesta que "es el sello de su corazón”, y que "el amor es tan valiente como la propia muerte”.

A todo esto, el canónigo estremece. El semblante se le ilumina. La pluma, plena de conmoción y respecto, completa el sustantivo con el adjetivo. Silvia caminará ahora a los pies de Silvio, en el sermón que el canónigo va a predicar un día próximo, e irán juntitos a la prensa, si él compila sus escritos, lo que no se sabe.

FIN 
Tradução de:

Eleonora Frenkel Barreto

eleonora.frenkel@gmail.com

Pós-doutoranda CAPES/PNPD, UNIOESTE

Fonte: "O Cônego ou Metafísica do Estilo". In: ASSIS, Machado de. Obra Completa. Rio de Janeiro : Nova Aguilar 1994. v. II. Disponível em: $<$ http://www.dominiopublico.gov.br/download/texto/bv000272.pdf>

\section{Referências}

BAKhtin, Mikhail. Questões de literatura e de estética. A teoria do romance. Tradução de Aurora F. Bernardini et al. São Paulo: Hucitec, 2010.

BAPTISTA, Abel Barros. A formação do nome. Campinas: UNICAMP, 2003.

BARThes, Roland. Crítica e verdade. Tradução de Leyla Perrone-Moisés. São Paulo: Perspectiva, 2003.

Berman, Antoine. A tradução e a letra ou o albergue do longínquo. Tradução de Marie-Hélène C. Torres, Mauri Furlan e Andréia Guerini. Rio de Janeiro: 7 Letras, 2007.

Bosı, Alfredo. Prólogo. In: Assis, Machado. Cuentos. Tradução de Santiago Kovadloff. Venezuela: Biblioteca Ayacucho, 1978, pp. ix-xxxix.

Cohen, Keith. “O New criticism nos Estados Unidos”. In: Luiz Costa Lima. Teoria da literatura em suas fontes. Rio de Janeiro: Francisco Alves, 1983, pp. 3-35.

DerridA, Jacques. Gramatologia. Tradução de Miriam Chnaiderman e Renato J. Ribeiro. São Paulo: Perspectiva, 2011.

GotLIB, Nádia Battella. Teoria do conto. São Paulo: Ática, 1985.

LiMA, Luiz Costa. Mímesis e modernidade. Formas das sombras. São Paulo: Paz e Terra, 2003.

MACHADO DE Assis, Joaquim Maria. "El canónigo o metafísica del estilo”. La iglesia del diablo y otros cuentos. Tradução de Remy Gorga Filho. Libresa: Quito, 2007, pp. 139-146.

"El canónigo o metafísica del estilo". Cuentos. Tradução de Santiago Kovadloff. Venezuela: Biblioteca Ayacucho, 1978, pp. 245-249.

. Diez historias cortas. Seleção, tradução, prólogo e notas de Pablo Rocca. Montevidéu: Ediciones de la Banda Oriental, 2006.

MoIsÉs, Leyla Perrone. Texto, crítica, escritura. SP: Ática, 1978.

PYM, Anthony. Exploring translation theories. London and New York: Routledge, 2010.

RoccA, Pablo. "Prólogo". In: Assis, Machado. Diez historias cortas. Montevidéu: Ediciones de la Banda Oriental, 2006, pp. 7-14. 